\title{
Arabian Uprisings As Harbinger Of Cold War
}

\author{
Timothy Ubelejit Nte
}

\begin{abstract}
The potential for internal conflicts to escalate can be very low or high depending on the forces aiding and abetting it. This is particularly true of the Arabian Spring Uprisings in general and the Syrian Crisis in particular which has degenerated into a new cold war. As was the case in the first cold war (1945-1989), vested imperial interest in the Arab World in particular and the Third World in general is the harbinger of the new cold war. The center for flexing of international muzzles is now Syria, whose crisis began like an internal uprising aimed at toppling the regime of Assad, based on the pattern of Tunisia, Egypt, Libya, Yemen and Qatar. It is part of the tussle for hegemonic control as manifest in proxy wars of the first cold war, in third world countries like Greece, Korea, Congo, Vietnam, Lebanon, Afghanistan, Angola, Mozambique, Cuba, El Salvador and Nicaragua. The article concludes that the world in general in now plunged into second cold war because of interferences in the affairs of Third World countries. It recommends that freehand and enough time should be giving to sovereign states to manage their internal affairs. It also recommends that human rights of a minority group should not dictate the pace or trend for an overwhelming majority of the population.
\end{abstract}

\section{Introduction}

There is apparently a symbiotic relationship between uprisings in Arab countries and Cold War both at the regional and global levels. This was the case in the First Cold War (1945-1989). The ongoing situation in Syria is reminiscent of that Cold War and may be tagged the "Second Cold War". What is obviously intriguing about the scenario is that it takes a similar shape at the regional levels. Fundamentally the bone of contention in this Second Cold war is the Syrian regime of President Bashar al-Assad. The events unfolding in the Syrian crisis has the internal, regional and international dimensions.

The crisis began like an internal uprising aimed at toppling the regime of Assad, based on the pattern of Tunisia, Egypt, Libya, Yemen and Qatar. It initially began with pockets of protests and agitations for reforms. As the protest gathered momentum in the city of Dir'a the government attempted to forcefully contain the agitated protesters. The crisis eventually escalated to demands for a change of Assad's regime. It eventually graduated into a regional tussle. At this regional level, Saudi Arabia, GCC and Turkey, support the opponents of the regime of Assad while Iran and Hezbollah of Lebanon support the proponents of the regime of Assad. It also has a tincture of Sunni-Shiite sectarian divide alignments.

The tussle also evokes the memories of the 1950s and 1960s Arab Cold War and inter-Arab power tussle during the era dominated by Egypt's President Gamal Abdel Nasser. The 1950s and 1960s Arab Cold War led to proxy wars in Yemen, Lebanon and Jordan. This was the case because of massive meddling in the internal affairs of affected Arab states which came in the form of assistance and intervention by the antagonist and protagonist.

At the global level the Syrian crisis has also degenerated into a new cold war by encompasses superpowers at the global levels. It would be recalled that there was major disaffection and disagreement between the United States of America and her allies on the one hand and the Union of the Soviet Socialist Republic or USSR (now Russia) on the other side immediately after the Second World War in 1945. The bipolar system prevalent at that time made the United States and Russia to be in a cold war for hegemonic control. They tussled not by direct hot war between themselves but by proxy wars which entails supporting, arming and financially assisting warring camps in third world countries like Greece, Korea, Congo, Vietnam, Lebanon, Afghanistan, Angola, Mozambique, Cuba, El Salvador and Nicaragua.

Instead of a direct nuclear war of mutually assured destruction (MAD) for the rivals in particular and perhaps the world in general, proxy wars were fought in third world countries of imperial interest. This was the case till the collapse of USSR in 1989, thus bringing the cold war to an end. The Arab Spring Uprisings in general and the Syrian Crisis in particular has engendered another cold war. It is indicative of a polarization within the comity of nations as made manifest after the Second World War. Obviously Arabian crises are harbingers of cold war.

\section{Arabian Cold War \\ The Syrian crisis which began as part of the Arab Spring Uprisings is now taking internal, regional and international dimensions. The crisis began like an internal uprising aimed at toppling the regime of Assad, based}


on the pattern of Tunisia, Egypt, Libya, Yemen and Qatar. It initially began with pockets of protests and agitations for reforms. As the protest gathered momentum in the city of Dir'a the government attempted to forcefully contain the agitated protesters. The crisis eventually escalated to demands for a change of Assad's regime. It eventually graduated into a regional tussle. At this regional level, Saudi Arabia, GCC and Turkey, support the opponents of the regime of Assad while Iran and Hezbollah of Lebanon support the proponents of the regime of Assad. It also has a tincture of Sunni-Shiite sectarian divide alignments.

The crisis also revives the memories of the 1950s and 1960s Arab Cold War and inter-Arab power tussle during the era dominated by Egypt's President Gamal Abdel Nasser. At this time, according to Ryan (2012) 'inter-Arab relations were characterized by power struggles between 'revolutionary' republics, led by pan-Arab nationalist military officers, and more conservative or even reactionary monarchies." He goes on to state that "[t]he republics saw themselves as the future of Arab politics, with the aim of changing not only the type of regime in Arab states, but also the map of the region through repeated unification efforts." The 1950s and 1960s Arab Cold War led to proxy wars in Yemen, Lebanon and Jordan. This was the case because of massive meddling in the internal affairs of affected Arab states which came in the form of assistance and intervention by the antagonist (Republicans and Monarchies).

The new Arab Cold War began with the Arab uprisings which began from the spring of 2011 and is still ongoing in Syria. As was the case with the 1950s Arab cold war the basic attributes are power struggles, ideological and identity conflicts, and proxy wars. In the ongoing (2011-2013) Arab cold war the monarchical regimes are rallying around each other in self-defence against the non-Arab threat of Iran. "Many Arab regimes were concerned not only with Iranian power, but also with Iranian influence and interference in Arab politics." [ibid]

The new Arab Cold War takes the shape of a power tussle between the Sunni Arabs led by Saudi Arabia and the Shia Arabs led by Iran. The Sunni's saw overwhelming usurpation of powers by Iran in the current political situation in Iraq and Lebanon where they are controlling Hezbolla; thereby tilting the balance of power which was originally in favour of the Sunni's. For this reason Saudi Arabia and Qatar are leading the Gulf Cooperation Council (GCC) countries to support the Free Syrian Army and other forces fighting to overthrow the regime of Assad. According to Ayoob (Jan 16, 2013) "The Saudi and Qatari governments are actively arming and provided financial support to the Syrian opposition, and the Gulf Cooperation Council (GCC) countries reportedly have sent weapons systems to the Free Syrian Army and other armed elements fighting the Assad regime...." Also on the side of the opposition or the Free Syrian Army fighting the regime of Assad is Turkey. On the other side of the power tussle is Iran which is fast becoming a force to be reckoned with in the Arab World. Together with Syria and heavily-armed Hezbollah movement they are directly and openly supporting the regime of Bashar al-Assad with fighting force and artillery.

Apart from Iran introducing the Shia versus Sunni sectarian element in the ongoing cold war for the crisis in Syria; it also constitutes a threat to the traditional monarchical institutions of the Arab world. Iran is inclined to empower a Shia crescent that would control and dominate power in the Middle East. Nevertheless what originally endeared Iraq with Syria in the network of cooperation alliances, was not the sectarian element of Shia nor Sunni but Iraq which was their common enemy. At the time of the aggression of Saddam Hussein which eventually led to the disastrous Iran-Iraq war, Syria supported Iran. Syria was the only regional state that supported Iran in this disastrous war. This was the basis for their alliance then and the bond has continued to be of mutual benefit to Iran and Syria. According to Hamilton "What originally brought Syria and Iran together was not the Shia sect, but Iraq - the common enemy both hated and feared"

Apart from carving a niche for hegemony, Saudi Arabia is involved in the proxy war and cold war to protect the interest of the monarchical institution in the Gulf Kingdoms or members of the Gulf Cooperation Council in particular and the Arab world in general. According to Ayoob (Jan 16, 2013) "Saudis and their monarchical allies in the Persian Gulf, keeping Iran bogged down in the Syrian quagmire diverts Tehran's attention and capabilities from the Gulf theatre. This benefits Gulf kingdoms apprehensive of the fallout from the Arab Spring on their own legitimacy and longevity." The monarchs of Saudi Arabia and other GCC regimes are so concerned at the unfolding cold war. You would recall that the GCC is an alliance of conservative Arab and Sunni hereditary monarchies for purposes of protecting their regimes against the restive peoples within their own borders.

The ongoing Cold War in the Arab world for Syria is reminiscent of the First Arab Cold War of the 1950 and 1960s. According to Ryan (op cit) "Often called the Iran-Saudi Arabia proxy war, it is a sectarian confrontation that mirrors the First Arab Cold War, when Nasser's secular Egypt led radical, pro-Soviet neighbours Syria and Iraq against a pro-US moderate front of religiously vested monarchies nominally headed by Saudi Arabia"

If history is anything to go by the ongoing proxy war and cold war would intensify because of victory desperation. The realization that the sectarian or ideological group that emerges victorious in the struggle for Syria would eventually rule Arab World is catapulting the crisis to higher and keenly contested dimensions. This 
is judging by the experience of the First Arab Cold War of the 1950s and 1960s between "revolutionary" military regimes espousing the cause of Arab nationalism and conservative monarchies determined to hold on to their power and privilege.

There are similarities and disparities in the First Arab Cold War (1950s and 60s) and the Second Arab Cold which started with the 2011 spring uprisings in Tunisia and extended to Egypt, Libya, Yemen, Bahrain and Syria. A major similarity is the mobilization of conservative monarchies in their quest to block the wave of change across the Arab world. There is also rivalry, power tussle and competing techniques of intervention at the sectarian dimension. The slight disparity is the impact of public opinion in the dynamics of the uprisings which the Second Cold War is contending with. "A public sphere expanded by a revolution in media and communication, a rise of Islamist social and political movements challenging incumbent regimes and, finally, new norms and popular expectations regarding participation in public life." [ibid] The Syrian crisis has eventually generated a new Arab Cold War.

\section{Incursion Of Second Cold War}

The conflict in Syria, to oust or retain the regime of Bashar al-Assad has degenerated into a new cold war, which this study refers to as the Second Cold War. This new cold war extends beyond the Arab world as it encompasses regional powers in the Arab World and superpowers at the global levels. It would be recalled that there was major disaffection and disagreement between the United States of America and her allies on the one hand and the Union of the Soviet Socialist Republic (Russia) on the other side immediately after the Second World War in 1945. According to Farmanfarmaian (Nov 13, 2012) "The First Cold War followed, as Soviet Russia and the US (Britain's maritime successor) contested for influence and power in the Middle East".

They tussled and battled for hegemony; not by direct hot war between themselves but by proxy wars which entails supporting, arming and financially assisting warring camps in third world countries. The cold war manifested in the form of proxy wars in third world countries like Greece, Korea, Congo, Vietnam, Lebanon, Afghanistan, Angola, Mozambique, Cuba, El Salvador and Nicaragua. Instead of a direct nuclear war of mutually assured destruction (MAD) for the rivals in particular and perhaps the world in general, proxy wars were fought in third world countries of imperial interest. The bipolar system prevalent at that time made the United States and Russia to be "engaged in the 'cold war' ideological propaganda against each other in a bid to prove their respective superiority". This was the case till the collapse of USSR in 1989.

The demise of the former Soviet Union and the abrupt end of the Cold War in 1989-1990 changed the fundamental dynamics of polarity, which was clearly bipolar in the post second world war period (1945-1989). In the post Cold War global system the United States overwhelmingly dominating the world as the sole superpower, taking decisions on global issues without intervention. The demise of the former Soviet Union and the awesome dominance of the United States was rightly predicted by Ayoob (1995) to "prompt the other superpower [the U.S.] to act even more cavalierly as far as the security interests of Third World states are concerned and tempt it to intervene militarily if developments in certain regions of the Third World that it considers strategically important are not to its liking." He went further to state that "Important Third World State elites, deprived of the presence of a balancing power that could in some measure neutralize the dominant superpower's interventionist proclivities, may therefore begin to feel more vulnerable and insecure." [ibid] This was the case in Serbia (1999) Iraq (2003) and Libya (2012).

In the post-Cold War world, America was the only superpower and Russia was relatively lukewarm. According to Hamilton (Jun 13, 2012) "Moscow did not take on NATO when its former Yugoslav ally Serbia was bombed by the Western alliance in 1999 over the civil war in Kosovo, or when the Western allies led by Washington invaded Iraq in 2003." The only exception was in the summer of 2008, when Russia stood her grounds in successfully backing the secessionist bid of South Ossetia, in Georgia which was a former Soviet republic. Russia declared war against Georgia in support of South Ossetia and although the United States and her allies opposed and verbally condemned Russia's action, they exercised restraint probably because of the proximity to Russia. Georgia is the immediate neighbor of Russia and this gave it that strategic home advantage in that conflict. The confrontation was however the very first time Russia defied all Western pressures and opposition to achieve her quest in the international system after the demise of the Soviet Union. It was reminiscent of the cold war days.

The success in wading off the pressures of the Western Forces in the course of the war in South Ossetia is a moral boaster in the ongoing conflict in Syria. Russia is now confronting the unilateral approach of the United States and its allies. As highlighted by Mike Spencer "The United States should not treat Russia as Jamaica and remember that after the United States, Russia has the highest number of nuclear warheads in comparison to any other country." [Mehdi 2012]

A major factor that is arousing this new consciousness in Russia to adamantly oppose the United States and her allies in interferences in third world countries in general and Syria in particular is "the realization of the deception and abuse of UN structure and resolutions, applying double standards to various global issues in 
different countries." [Vladimir Putin] Contemporary Russian international relations experts "maintain that the current foreign policy of the United States is based on two theories: 'ultimate realism,' and 'new liberalism.' As a result, the Americans actually believe that world countries are simply divided into the United States' friends and enemies." [op cit]

The conflict in Syria in particular and the Arab Spring Uprisings in general has sparked up another cold war. A second cold war indeed aided and abetted by global cold war dynamics and forces like the United States, Britain and France on the one hand and Russia and China on the other hand. The divide is such that the United States, Britain and France are supporting the Free Syrian Army who are rebels fighting to overthrow the regime of Bashar al-Assad. Russia and China are proponents of the regime of Assad and are supporting those fighting the opposition. According to Ayoob (Jan 16, 2013) "Russia and China have so far resisted Western calls to put pressure on Assad to resign. They have also vetoed three UN Security Council resolutions seeking to impose sanctions on Syria, the most recent on July 19, 2012"

The United States of America is oblivious of the consequences of directly invading Syria without a Security Council endorsement and would surely not toe that path. The lesson of Iraqi invasion without Security Council authorization left the image of the Unites States in tatters and this is still trailing them. For this reason "the United States has cranked up its anti-Assad rhetoric and covertly supported the armed opposition, it has refrained from direct military intervention in Syria." [ibid] This is reminiscent of the cold war in all its ramifications.

There are ample reasons to assert that Russia and China would maintain their stance judging by previous bitter experiences mostly in Iraq and Libya where the United States and her allies used United Nations Resolutions 1441 and 1973 to surreptitiously achieve their ulterior goals. According to Julian (Sep 2012) "Both Russia and China feel badly burned by allowing security council resolution 1973 to pass in March 2011 authorising 'all necessary measures' to protect Libyan civilians, which was then used by NATO as a mandate to help topple Muammar Gaddafi." He goes further to state that "The ghosts of the 2003 Iraq invasion and the furious debates that preceded it still hang in the air. ...it helped reverse what was arguably one of the great moral advances of the post-cold-war era." More importantly, the power ratings of Russia and China have greatly accelerated in the international arena and could successfully withstand pressures of compromise from the United States.

The conflict in Syria underscores the power game of the imperial powers in the Middle East in general and the Third World in general. The proclivity of the United States and her Western allies to interfere in the affairs of Third World countries without constraints is now been curtailed by Russia and China. The veto of Russia and China, on February 4, 2012 against the United Nations Security Council Resolution calling for President Bashar al-Assad to step down was a boiling point in the ongoing Cold War. The resolution was sponsored by the United States and her Western and Middle East allies.

The situation is like blatantly telling the sole superpower in the post-cold war era that she is no longer the exclusive custodian of power or the only cock that can crow in the international system. The cold-war is back and the hegemony of the United States as the sole superpower is again been challenged. According to Hamilton (op cit) "[a]t a stroke, the debate was no longer simply about Syria's internal power struggle. Instead, with their vetoes, Moscow and Beijing were saying that they too had interests in the Middle East that they were determined to protect."

The rationale behind this new cold war is that like the Western forces, Russia and China also have ulterior vested interest in the Middle East in particular and the Third World in general. This is the reason for the very active involvement of Russia in supplying arms and financial support. According to Barry (Feb 9, 2012), "Russia has shipped arms during the uprising to Assad's government allegedly for use against rebels." The same is applicable to China who is trying to protect her vested interest in the Middle East by opposing regimes that would be puppets to Western Forces led by the United States. China is also a major client of Iran oil sector. According to Shafiq (2012) "By backing Syria, China prevents the political dominoes from falling into Iran, a strategic 'anti-western' entity."

Over the post cold war years, Russia has been redundant in vital international decision making and is now feeling that the Western forces are now taking her for granted. According to Salam (Jul 9, 2012) "Russia has been feeling a sense of marginalization and a weakening of respect on the international front since the collapse of the USSR." Apparently Western forces have misconstrued this lukewarm posture for weakness and have taken undue advantage of it to propagate and achieve their ulterior motives and vested interest at the expense of Russia who has now noticed the slight of inactive position and relegation to the background on international issues. "Several of the major agenda items (the Balkans and Iraq for instance) have been handled far away from Russia's influence. Syria now pays the price of this Russian desire to regain control, as it seeks an acknowledgement of its international position and weight." [ibid]

On a general note Vladimir Putin of Russia and Hu Jintao of China are interested in the Arab Spring Uprisings because of its potential adverse effects on their ideology and political philosophy in line with public 
revolts, uprisings and rebellion to constituted authorities. Russia and China permit the use of brutal force to suppress such oppositions without consideration for human rights. "Both fear contagion from the Arab Revolutions and may prefer a template where rebellion is ruthlessly and bloodily suppressed." [Abdel Jun 2012]

In the case of the United States, the close ties between the Regime of Assad and that of Ahmadinajad of Iran is a major cause for alarm. Also his links and sponsorship of Hezbollah Terrorist Organisation in Lebanon leaves much to be desired. According to Ayoob [Jan 16, 2013] "Assad's relationship with Iran incents the United States to seek the regime's removal. Washington worries that post-Assad Syria may unleash the anarchy and violence seen in Iraq after Saddam." Apparently, this is the reason why the United States is so concerned about the outcome and is going all out to secure a favourable result. "Washington's outrage at the challenge was evident when U.S. Secretary of State Hilary Clinton angrily dismissed the Russian and Chinese veto as a 'travesty."' [Seale Aug 2, 2012]

The United States has mustered support from other nations in the form of a coalition which would help achieve their goal. This is what gave rise to the "Friends of Syria" a coalition of countries cajoled by the United States to be favourable disposed and willing to show solidarity to the course of overthrowing the regime of Assad. The Friends of Syria include countries like USA, UK, France, Turkey, Saudi Arabia, Jordan, Egypt, Kuwait, UAE, Qatar, Tunisia, Morocco etc. At a meeting recently hosted in Istanbul, Turkey, the group reiterated their commitment to oust Bashar al-Assad.

On the other hand Russia is also cajoling solidarity through the Shanghai Cooperation Organisation (SCO). The SCO is made of countries like Russia, China, Iran, Kazakhstan, Kyrgyzstan, Tajikistan, and Uzbekistan. According to Abdel [op cit] "At their meeting in Beijing last week, the Shanghai Co-operation Organisation (SCO), led by Russia and China, re-iterated their opposition to military intervention, western interference and imposed regime change in Syria." The differences currently centre on Syria and what SCO spokespeople have referred to as the West's 'neo-interventionism' which they say is based on a spurious 'dislike' of 'a country's system.' [ibid] The Arab Spring Uprisings in general and the Syrian crisis in particular has generated a second cold war.

\section{Background Of Russian Solidary In The Syrian Crisis}

We noticed above how the issue of Syria has dragged Russia out of its shell and made it to go extra mile, damning potential consequence in the quest to protect the Assad regime in Syria. The question here is why Syria? Over the years, beginning as far back as the late $19^{\text {th }}$ and early $20^{\text {th }}$ centuries, Syria has been a very strong ally of Russia. The two countries have enjoyed close links and diplomatic relationship long before Syria was formally accorded independence on 17 April 1946 and recognized as a sovereign state. According to Kreutz (2007) "Russia's political presence in Syria predates the creation of the modern Syrian state after World War II"

Syria is Russia's closest Middle Eastern ally and the both countries have endeared themselves together. Russia has given Syria substantial military and economic aid. "In 1893, a Russian consular office was established in Damascus, further cementing the relationship. By 1905, the Imperial Russian Orthodox Society had opened 74 schools in Syria, but by 1910, the society was spending most of its income on Syrian education. Also "between 1955 and 1958, Syria received about \$294 million from Moscow for military and economic assistance" [ibid].

During the period of the Suez War and the consequent Cold War generated by it Syria was a major ally of the Soviet Union (Russia) and was aided and abetted alongside Egypt and other allies to fight against the Western forces. According to Mansfield (2010) "In 1956 Syria followed Egypt in acquiring arms from the Soviet Union, and the Suez War accelerated a multiplication of ties between Syria and the Soviet Union - ties closely associated with the increase in power and influence of the Ba'ath Party." Thousands of Syrian military officers and educated professionals studied in Russia during the senior Assad's four-decade rule, and such connections have resulted in many marriages and mixed families. [Peel and Clover (2012)]

Russia's only military base in the Middle East is located in Tartus, Syria. Tartus is a vital source of influence and authority because it is Russia's sole foothold in the Mediterranean. According to Ayoob (Jan 16, 2013) "Russia's sole military base outside the countries that formed the former Soviet Union is located in Tartus, Syria, and that should not be underestimated as a psychological factor for Moscow." Also Syria is one of the longest-standing allies of Russia.

In the ongoing conflict in Syria Russia has provided assorted military hardware to assist the regime of Assad this includes "MI-25 helicopter gunships, the country has also transferred to Syria the Buk-M2 air defense system, the Bastion coastal defence missile system, and Yak-130 combat jet trainer [Sayginer]. Russian shipments of fuel have also assisted Assad, and an unspecified number of military advisers are teaching Syrians how to use Russian weapons. [Donati and Payne] Russia is overtly supporting the Assad regime without any apologies and in defiance of Western pressures. This was acknowledged by Russia's foreign minister Sergei Lavrov who "defended his country's sale of arms to Syria, an ally for decades where Moscow has Mediterranean port facilities." [Hamilton op cit] 
On the part of the incumbent Syrian government, Bashar al-Assad is adamantly fighting the opposition and gathering any support he can muster because of the outcome of some of the Arab spring uprisings. Tunisia and Egypt succumbed to the pressures of Western public opinion and allowed the mutineers to have their way. Before the Arab Spring Uprisings both Zine Ben Ali of Tunisia and Hosni Mubarak of Egypt had long standing alliances and friendly disposition towards the West and respected their opinion. They were praised as "moderates" and not "radicals" because they stepped down. But the outcome leaves much to be desires because both Ben Ali and Mubarak are now facing the bitter consequences without intervention by the same Western powers that encouraged them to bow to the dictates of the "rebels". The knowledge of the killing of Muammar Gaddafi is another issue that should harden the minds of Assad to the pressures of Western forces and seek the support of Russia. "Assad has seen the death of Gaddafi in Libya and the fate of Mubarak in Egypt and he understands he has no choice. He knows his Alawite minority will be slaughtered." [ibid]

This is compounded by the ethnic divide in Syria. As opposed to Iran or Egypt who are truly nation states with insignificant ethnic divisions, Syria has multiple ethnicities. Sectarian violence can easily lead to agitation for autonomy or new states. Apparently because of the arbitral boundaries of Syria the crisis may degenerate into irredentism or secession movements by rebels. "Syria's creation by colonial powers Britain and France after the First World War, on what look like arbitrary geographical lines that disregard tribal and ethnic distinctions" [ibid] is a major factor that can accelerate the crisis.

Evidently Bashar al-Assad has been anticipating crisis of this magnitude. This is because he equipped his military forces with sophisticated state of the arts weapons. Report has it that the regime of Assad has arms and ammunition that dwarfs all the collections of Gaddafi. "President Bashar al-Assad is said by Jane's Terrorism and Security Report to have an arms stockpile twice as powerful as that of Muammar Gadaffi's, and with reports of Russia eager to top up supplies, it looks as if the conflict could last". [ibid] His prospects are enhanced by the overwhelming support of Russia and Iran as well as the presence of Hezbollah.

The summary of it all is that the solidarity that Russia is showering on the Syrian crisis is predicated on a number of factors. Russia has vested interest in the Syrian regime because of their long standing political history. There have been cordial diplomatic relationship, mutual cooperation and major trade deals between the two countries. Syria is one of the longest standing allies of Russia and the abode of Tartus - the sole military base of Russia in the Middle East. In the crucial cold war years (1945-1989) Syria unflinchingly showed solidarity and alliance with Russia. On the side of the regime of Assad, he is prepared and willing to garner any support he could muster from Russia, Iran and Hezbollah. This would keep the new cold war raging for awhile.

\section{Conclusion And Recommendations}

The specter of regional and global tension and insecurity is dependent on the forces that are willing to partake in the macabre dance. This is particularly true of the prevalent cold war at the regional and international levels. Conventionally, governments of sovereign states are allowed freehand and enough time to handle internal opposition and turmoil. This well recognized and acceptable international best practice is always shredded in the internal crisis and turmoil of weak Third World countries as Western powers often take advantage of it to intervene in countries that they stand to bountiful benefit. This is the cause of the ongoing cold war generated by Arab Spring Uprisings in general and the Syrian crisis in general.

It works like the domino theory. Western forces did not allow Ben Alli enough time and free hand to suppress opposition and his regime was successful overthrown by the rebels. The population of Egypt noticing that Western forces would always condemn brutal suppression of revolts took advantage of the Western leverage of liberty and human rights to overthrow Mubarak. Libya knowing that silence in the face of opposition would bring down a regime tenaciously fought the opposition but was recklessly supported by Western forces and this led to the killing of Gaddafi. Bahrain was next in line as the masses also wanted "reforms". Apparently the reforms are more in the area of overthrowing a regime to cling to power. Unfortunately this time around there was forceful crushing of the uprising in Bahrain by the al-Khalifa regime. Thanks to the free hand and enough time giving by the West.

Seemingly irked by the level of condemnation from the international community about the intervention in Libya which led to the killing of Gaddafi, Western forces were not bordered about the management of the internal conflict in Bahrain by the constituted authorities of that sovereign state.

Obviously the support for the regime of al-Khalifa of Bahrain and President Ali Abdullah Saleh of Yemen despite the fact that the both regimes are guilty of the same offences of no democracy and brutal suppression of persons protesting and agitating for reforms as was in Libya and Syria shows that there is more to the propaganda. Evidently regime change becomes an agenda not because of democracy but because the regimes have seized to compromise the imperialistic overtures which infringes on the territorial integrity and sovereignty of their countries. This was the case with Muammar Gaddafi of Libya and Bashar al Assad of Syria. In each of these cases their regimes became targets for change because they where major stalwarts against imperialist overtures and proclaimed a national agenda that were tinted with anti-imperialistic exploitations. 
The ulterior motive for the change of their regimes was to establish a new puppet regime that would serve to consolidate and actualize economic and geo-strategic imperial interests in Third World countries.

More importantly Western forces have clamoured to maintain their hegemonic control of the world. The tussle for Syria underscores the power-game between the United States and her allies on the one hand and Russia and China on the other hand. It is a revival of cold war confrontations similar to those before the post cold war age (1945-1989) were proxy wars were fought by superpowers of the then bipolar world order. In the battle for hegemony proxy wars were fought in Greece, Korea, Vietnam, Lebanon, Congo, Afghanistan, Angola, Mozambique, Cuba, El Salvador and Nicaragua.

The ghost of Saddam Hussein and Muammar Gaddafi is haunting Russia because she was not proactive enough in the international decisions that led to their execution. Russia is now realizing the weakening of his status and systematic marginalization in the international front. To forestall similar imperialistic interventions and executions, Russia is fully back to serve as check and balance to the United States and her allies and this has revived the cold war.

The article recommends that freehand and enough time should be giving to sovereign states to manage their internal uprisings, oppositions and crisis as was the case with Bahrain. Unfortunately the world in general is now plunged into a cold war because of interventions by Western forces which Russia and China is wary about.

Personal liberty and human rights of a relatively insignificant minority group should not dictate the pace or trend for an overwhelming majority of the population. The use of force to maintain peace should not be condemned by Western forces as an anathema to abet the humanitarian catastrophe of a whole country as was the case in Iraq, Libya and now Syria. The procedure is tantamount to robbing Peter and many others to pay Paul.

This becomes more pertinent when the personal liberty, human rights and humanitarian mission criteria for intervention is selective without universal applicability. There was relative silence and inaction as the uprising in Bahrain was brutally crushed by the al-Khalifa regime. Evidently Western forces supported the regime of al-Khalifa in this exercise despite its much trumpeted propaganda of democracy and human rights. The same democratic reform propaganda is the reason for supporting the rebels fighting the Syrian regime of Assad.

The awareness of this crystal clear double standard of Western powers and the knowledge of their ulterior imperialistic motives is what is generating this second cold war. Evidently Arabian crises are harbingers of cold war.

\section{References}

[1]. Abdel Bari Atwan (Jun 2012), Civil war in Syria can become proxy war for big powers, in Gulf News, @ http://gulfnews.com/ opinions/columnists/ civil-war-in-syria-can-become-proxy-war-for-big-powers-1.1034593

[2]. Ake Claude (1992), The New World Order: A View From the South, Malthouse Press for Centre for Advanced Social Science, Lagos

[3]. Ayoob Mohammed (1995), The Security Predicament of the Third World State: Reflections on State Making in a Comparative Perspective, in Brian L. Job (ed), The Insecurity Dilemma - National Security of Third World States, Lynee Rienner Publishers, London

[4]. Ayoob Mohammed (Jan 16, 2013), The New Cold War in the Middle East, published by "The National Interest Journal" http://nationalinterest.org/ commentary/the-new-cold-war-the-middle-east-7974

[5]. Barry Anya (Feb 9, 2012), Adding Fuel to Syria's Fire, cited in Wikipedia the Free Encyclopedia

[6]. Donati Jessica and Julia Payne (26 Apr 2012), How Russia, Iran keep fuel flowing to Syria, published by "Reuters"

[7]. Farmanfarmaian Roxane (Nov 13, 2012), Redrawing the Middle East map: Iran, Syria and the new Cold War, published by "Aljazeera" http://www.aljazeera.com/indepth/opinion/2012/11/2012111311424048459.html

[8]. Gauba O. P. (2007), An Introduction to Political Theory, Macmillan India Ltd, Ansari Road, Daryaganj, New Delhi 110 002, Fourth Edition

[9]. Hamilton Douglas (Jun 13, 2012), Russia-America tussle over Syria evokes Cold War, published by "Tel Aviv" @ http://www.reuters.com/ article /2012/06/13/us-syria-coldwar-israel-idUSBRE85C10W20120613

[10]. Julian Borger (Sep 2012), Syria crisis widens faultines at divided UN, published in The Guardian, http://www.guardian.co.uk/world/2012/sep/24/syria-widens-faultlines-divided-un

[11]. Kreutz Andrej (2007), Russia in the Middle East: friend or foe?, Westport, Connecticut: Greenwood Publishing Group.

[12]. Mac Ogonor C. U. (2000), The UN, NATO and The Post Cold War Management of Global Peace, Rostian Port Harcourt

[13]. Mansfield Peter (2010), A History of the Middle East, Penguin 2010, 3rd edition, p.293

[14]. Mehdi Sanaei (Aug, 2012), Russia and the New Cold War in Syria, published by "Iran and Eurasia Research Center," http://www.iranreview.org/content/ Documents/Russia-and-the-New-Cold-War-in-Syria.htm

[15]. Mike Spencer, in Mehdi Sanaei (Aug, 2012), Russia and the New Cold War in Syria, published by "Iran and Eurasia Research Center," http://www.iranreview.org/content/Documents/Russia-and-the-New-Cold-War-in-Syria.htm

[16]. Peel Michael and Clover Charles (Jul 9, 2012), Syria and Russia's special relationship, in Wikipedia the free Encyclopedia

[17]. Ryan Curtis (2012), The New Arab Cold War and the Struggle for Syria, published by Middle East Research and Information Project @ http://www.merip.org/mer/mer262/new-arab-cold-war-struggle-syria

[18]. Salam Al-Kawakibi (Jul 9, 2012), A multi polar cold war at the expense of Syrians, published in Open Democracy, http://www.opendemocracy.net

[19]. Sayginer Ozge (20 Jun 2012), Why Russia will never back down? Reasons behind supporting the Assad regime", published in The European Strategist

[20]. Seale Patrick (Aug 2, 2012), Syria and the new cold war, published in The Diplomat @ http://thediplomat.com/2012/02/08/syria-andthe-new-cold-war/

[21]. Shafiq Morton (2012), Syria: The Cold War Continues, published in "The Palestine Chronicle" @ http://palestinechronicle.com/syria-the-cold-war-continues/

[22]. Vladimir Putin, in Mehdi Sanaei (Aug, 2012), Russia and the New Cold War, in Syria, published by "Iran and Eurasia Research Center," http://www.iranreview.org/content/Documents/Russia-and-the-New-Cold-War-in-Syria.htm 